\title{
PERLUNYA KEADILAN RESTORATIF DALAM SISTIM PERADILAN ANAK TERHADAP KENAKALAN REMAJA
}

\author{
Wandi Subroto \\ Sekolah Tinggi Ilmu Hukum Rahmaniyah, Sekayu \\ Email: wandi.stuhr@gmail.com
}

\begin{abstract}
Abstrak
Anak-anak dan remaja adalah aset bangsa yang paling penting, dan mereka harus dilindungi dari pengaruh berbahaya yang dapat menyebabkan kenakalan remaja, yang mengarah pada kegiatan kriminal, dan pidana. Di Indonesia, kejahatan dihukum sesuai dengan keputusan pengadilan. Jika dilakukan pada anak-anak atau remaja, dapat menimbulkan stigma negatif dan diskriminasi yang dapat berdampak pada perkembangan mereka di masa depan. Untuk itu, pendekatan lain terhadap kasus hukum terkait anak, seperti keadilan restoratif, harus dipertimbangkan. Oleh karena itu, penelitian ini mencoba mengkaji dampak restorative justice di pengadilan anak di Indonesia. Metode penelitian yang digunakan adalah penelitian hukum yuridis normatif, dan strategi penelitiannya adalah penelitian hukum. Sumber data sekunder meliputi studi literatur dan dokumen. Hasil penelitian menyimpulkan bahwa keadilan restoratif merupakan salah satu alternatif penyelesaian permasalahan hukum di luar pengadilan, sebagaimana tertuang dalam Undang-Undang Nomor 11 Tahun 2012 tentang Sistem Peradilan Anak yang menekankan pada musyawarah antara pelaku, korban, keluarga, dan pihak terkait. Pemulihan, bukan balas dendam, adalah tujuannya.
\end{abstract}

Kata Kunci: Keadilan Restoratif, Kenakalan Remaja, Sistim Peradilan Anak.

Abstract

Children and adolescents are the nation's most important assets, and they must be protected from harmful influences that might lead to juvenile delinquency, which leads to criminal activities, and punishment by the law. In Indonesia, a crime is punished according to the court's ruling. If done to children or teenagers, it can lead to negative stigma and discrimination that can impact their future development. For this reason, other approaches to child-related legal cases, such as restorative justice, must be considered. As a result, this study seeks to assess the impact of restorative justice in Indonesian juvenile courts. The research method used is normative juridical legal research, and the research strategy is legal. Secondary data sources include literature and document investigations. The research concluded that diversion is one of the alternatives for addressing legal issues outside of court, as stated in Law No. 11 of 2012 about the Juvenile Justice System, stressing deliberation among perpetrators, victims, families, and connected parties. Recovery, not vengeance, is the aim.

Keywords: Restorative Justice, Juvenile Delinquency, Juvenile Justice System.

\section{A. PENDAHULUAN}

Hukum merupakan suatu sistem yang erat kaitannya dengan kehidupan masyarakat (Salam, 2017). Padahal, dengan perkembangan dinamika masyarakat yang semakin kompleks, hukum juga harus mengembangkan persyaratan yang harus menjadi bagian dari setiap zaman. Perkembangan peradaban manusia tidak hanya berdampak positif bagi kehidupan manusia, tetapi mau tidak mau juga memunculkan bibit-bibit kejahatan baru yang memerlukan 
penanganan yang cepat dan efektif terhadap semua pihak dan semua pihak (Arief, 1998). Oleh karena itu, dalam penegakan hukum, kesadaran masyarakat dan pengembangan cita-cita hukum dalam masyarakat menjadi sangat penting. Dalam membuat undang-undang, opini publik memegang peranan penting (Mochtar Kusuma Atmadja, 1976). Penegakan hukum menjadi basi karena kurangnya inovasi (fadri, 2010).

Sistem peradilan yang baik dan sehat tentunya akan mampu menjamin keadilan, keamanan dan keselamatan warga negara, serta kemampuan menimbulkan kepercayaan dan rasa hormat dari masyarakat, pada hakikatnya merupakan turunan dari kekuatan non fisik yang perlu dilestarikan untuk mencapai tujuan keberlanjutan untuk generasi mendatang (Suntoro, 2020). Sistem penegakan hukum merupakan satu kesatuan sistem yang memadukan antara sistem peradilan dan sistem kekuasaan kehakiman. Sistem Peradilan Pidana merupakan tahapan panjang kewajaran yang akan dilaksanakan oleh aparat penegak hukum sesuai dengan kewenangannya masing-masing (Setiadi, 2017).

Anak-anak adalah aset paling berharga bagi keluarga, masyarakat, atau bangsa mana pun, dan mereka juga yang paling rentan. Mereka adalah pertemuan di mana keluarga, komunitas, dan bangsa mengandalkan harapan, terutama anak muda, yang akan menentukan apakah suatu negara berada di jalan menuju kemakmuran atau bencana (Hasibuan, 2019). Menurut konstitusi Indonesia, anak memainkan peran penting, dan negara secara khusus berkomitmen untuk memastikan bahwa hak setiap anak untuk kelangsungan hidup, perkembangan, serta perlindungan dari kekerasan dan diskriminasi, dilindungi. Akibatnya, kepentingan terbaik anak harus dihidupi sebagaimana kepentingan terbaik bagi kelangsungan hidup umat manusia harus dihidupi (Ariani, 2014). Sesuai dengan Undang-undang Perlindungan Anak Nomor 17 Tahun 2016 tentang Perlindungan Anak yang kesemuanya memberikan prinsip-prinsip umum perlindungan anak, antara lain nondiskriminasi, kepentingan terbaik bagi anak, kelangsungan hidup dan tumbuh kembang, serta penghormatan terhadap partisipasi anak, maka ketentuan ini diundangkan.

Upaya dan tindakan orang-orang di semua lapisan masyarakat, dalam semua posisi dan tanggung jawab, yang menyadari sepenuhnya pentingnya anak bagi negara dan bangsa di masa depan yang dikenal sebagai upaya dan kegiatan perlindungan anak. Jika mereka telah mencapai tingkat kedewasaan tertentu dalam perkembangan fisik, mental, dan sosialnya, maka sudah saatnya untuk menggantikan generasi sebelumnya (Ariman \& Albariansyah, 2014). Sifat kekanak-kanakan memerlukan pertimbangan khusus terutama karena fakta bahwa keadaan fisik dan mental mereka masih muda dan secara inheren tidak stabil. Untuk menjamin bahwa apabila seorang anak melakukan tindak pidana kenakalan, maka penanganan dan penyelesaiannya akan dilakukan dengan sebijaksana dan secermat mungkin, dengan menghindari campur tangan dari sistem peradilan dengan tidak mengabaikan penegakan hukum dan keadilan, guna menjamin terselenggaranya pendidikan yang baik. penyelesaian yang dilakukan terhadap anak, maka prinsip-prinsip berikut harus diikuti: demi kesejahteraan anak yang bersangkutan dan kepentingan umum bagi anak yang melakukan perilaku nakal (Waqiah, 2021).

Kita perlu memperhatikan dampak negatif dari perkembangan pesat, globalisasi dalam komunikasi dan informasi, kemajuan ilmu pengetahuan dan teknologi, serta perubahan gaya dan cara hidup orang tua, di masa globalisasi ini, di mana anak-anak hadir. Nilai-nilai dan perilaku dalam masyarakat sangat dipengaruhi oleh norma-norma sosial, yang pada gilirannya 
menyebabkan meningkatnya kejahatan dan memburuknya kualitas kejahatan itu (Purwati \& Alam, 2015).

Kenakalan remaja, kejahatan yang dilakukan oleh anak, merupakan indikasi yang jelas dari kurangnya perhatian orang tua dan masyarakat terhadap perilaku anak. Anak muda antara usia 12 dan 18 tahun masih dalam masa perkembangan yang lebih rentan terhadap pengaruh dari dunia luar, seperti panutan dan sekolah. Ini membuatnya lebih mudah bagi mereka untuk membentuk asosiasi yang salah. Untuk itu, masyarakat dan orang tua harus memberikan perhatian khusus kepada anak pada masa ini, saat mereka paling rentan terhadap pengaruh negatif. Di era globalisasi, anak muda mampu melakukan berbagai kejahatan keji, termasuk pembunuhan, pencurian, perusakan, pencabulan, kekerasan seksual, dan sejumlah pelanggaran lainnya (Hambali, 2019).

Rutan dapat menerima anak yang telah melakukan tindak pidana atau menjadi "anak bermasalah" sebagaimana diatur dalam Undang-Undang Nomor 11 Tahun 2012 tentang Sistem Peradilan Pidana Anak. Banyak anak harus berurusan dengan sistem pengadilan dan ditempatkan di tempat penahanan dan penjara dengan orang dewasa, sehingga mereka menjadi sasaran kekerasan, yang tentu saja bertentangan dengan prinsip perlindungan anak yang secara khusus menangani prinsip ini. Kondisi ini jelas cukup mengganggu.

Jelas bahwa anak-anak yang ditempatkan di penjara sebagai akibat dari sistem peradilan pidana formal memiliki efek negatif jangka panjang pada perkembangan mereka. Metode sistem peradilan pidana formal untuk menghukum anak-anak dengan mengurung mereka di penjara tidak berhasil mencegah mereka berperilaku tidak baik atau membantu mereka tumbuh menjadi orang yang lebih baik. Anak-anak yang dijebloskan ke penjara umumnya lebih baik dalam melakukan kejahatan karena pelatihan yang mereka terima di penjara.

\section{B. METODE}

Pendekatan normatif-yuridis diadopsi dalam penelitian ini. Jenis studi hukum ini juga dikenal sebagai "hukum perpustakaan," dan merupakan jenis penelitian yang meneliti bahan pustaka atau data sekunder dan kemudian menerapkan temuan untuk pertanyaan penelitian tertentu, seperti perlunya keadilan restoratif untuk memerangi kenakalan remaja. serta gagasan dan teori hukum yang sesuai (Soekanto, 2007). Uraian tentang tantangan dan tujuan penelitian disediakan dalam spesifikasi penelitian. Investigasi di mana beberapa variabel yang terkait dengan masalah yang diselidiki dijelaskan.

\section{HASIL DAN PEMBAHASAN}

Penyelesaian konflik mencerminkan proses sosial dan hubungan, dengan anak-anak yang mampu menyelesaikan perselisihan secara damai memiliki peluang lebih besar untuk terlibat dalam persahabatan dan mencapai penerimaan teman sebaya. Selain itu, mediasi keluarga telah banyak digunakan untuk membantu orang tua menyepakati isu-isu mengenai anak-anak mereka dan guru di sekolah memperkenalkan program pelatihan untuk memberdayakan keterampilan siswa untuk mengatasi konflik. Selain itu, penyelesaian sengketa alternatif tidak hanya mengacu pada penyelesaian sengketa sederhana, tetapi juga dirujuk ke penyelesaian sengketa tradisional tambahan melalui litigasi, atau khususnya, ke ajudikasi oleh pengadilan. Jelaslah bahwa alternatif penyelesaian sengketa seperti pendekatan restoratif peradilan anak yang telah dimasukkan dalam Undang-Undang Nomor 11 Tahun 2012 
tentang Sistem Peradilan Anak (selanjutnya disebut UU SPA 2012) berpotensi efektif dalam menangani anak di bertentangan dengan hukum karena mengakui bahwa kepentingan terbaik anak harus didahulukan dalam menangani anak yang melakukan kejahatan.

Tujuan keadilan restoratif adalah untuk memberdayakan korban, masyarakat, pelaku dan keluarga untuk memulihkan efek dari peristiwa berbahaya, menggunakan upacara penyesalan yang efektif. Beberapa aspek keadilan restoratif telah diatur dalam undang-undang Indonesia yang ada, yaitu; Undang-undang Perlindungan Anak Nomor 17 Tahun 2016 yang mengatur bahwa pengadilan pidana merupakan upaya terakhir untuk menangani kenakalan remaja yang sesuai dengan Konvensi Hak Anak Perserikatan Bangsa-Bangsa dan UndangUndang Hak Asasi Manusia Nomor 39 Tahun 1999 yang menyatakan bahwa sidang pengadilan adalah pilihan paling sedikit dalam menangani pelaku anak. Saat ini, undang-undang terpenting dalam sistem peradilan pidana anak adalah Undang-Undang Nomor 11 Tahun 2012 tentang Sistem Peradilan Anak, yang telah mengubah sistem hukum Indonesia menangani pelaku anak secara progresif.

Hak-hak anak harus dilindungi bahkan jika sistem peradilan pidana mengharuskannya. Berdasarkan Pasal 3 Konvensi PBB tentang Hak Anak, hak-hak anak yang berkonflik dengan hukum dilindungi dan dipenuhi sebagai berikut:

1. Kepentingan terbaik anak harus menjadi prioritas pertama dalam semua kegiatan yang melibatkan anak, baik oleh lembaga kesejahteraan sosial negara atau swasta, pengadilan, otoritas administratif atau badan legislatif;

2. Negara-negara Pihak setuju untuk mengambil semua tindakan legislatif dan administratif yang diperlukan untuk menjamin keselamatan dan kesejahteraan anakanak, dengan mempertimbangkan hak dan kewajiban orang tua mereka, wali hukum, dan badan hukum lainnya yang memiliki hak asuh atas mereka;

3. Negara-negara pihak harus memastikan bahwa berbagai lembaga, layanan, dan fasilitas yang ditugaskan untuk merawat dan melindungi anak-anak didanai dan dikelola dengan baik.

Menanggapi diversi dalam UU SPA 2012, Pemerintah Indonesia telah menetapkan Peraturan Pemerintah Republik Indonesia Nomor 65 Tahun 2015 tentang Pedoman Pelaksanaan dan Tindakan Diversi Terhadap Anak Di Bawah 12 Tahun. Pasal 5 (2) Peraturan Pemerintah tersebut menyatakan bahwa apabila diperlukan proses diversi dapat melibatkan pekerja kesejahteraan sosial dan atau masyarakat. Selain itu, Mahkamah Agung RI merespon implementasi UU SPA 2012 dengan menerbitkan Peraturan Nomor 4 Tahun 2014 tentang Pedoman Pelaksanaan Diversi Dalam Sistem Peradilan Anak. Hal tersebut telah memasukkan perlunya pendekatan restoratif peradilan anak dalam penyelenggaraan diversi terhadap anak di Indonesia. Pasal 1 (1) Peraturan ini mengatur bahwa konferensi diversi adalah pertemuan antara pihak remaja dan orang tua/wali, korban dan/atau orang tua/wali, petugas percobaan, pekerja sosial profesional, perwakilan masyarakat dan pihak lain yang berkepentingan untuk kasus ini untuk mencapai diversi melalui pendekatan keadilan restoratif.

Keadilan restoratif menurut Fathurokhman (2013) pada hakekatnya sama dengan musyawarah dalam budaya hukum Indonesia. Dia juga menegaskan bahwa kelompok tersebut telah mencapai konsensus sebagai konsekuensi dari diskusi dan kesepakatan yang panjang. Keadilan restoratif sangat populer di Indonesia, di mana individu sangat ingin membantu anakanak yang dirugikan. Penyelesaian divergensi dalam UU SPA 2012 dimungkinkan melalui 
proses restorative justice, yang menyerupai perdebatan dalam hukum Indonesia (Faturokhman, 2013). Pertemuan diversi harus selalu melibatkan anak, orang tua atau walinya, korban dan keluarganya, petugas masa percobaan dan pekerja sosial yang terlatih dalam keadilan restoratif. Hal ini secara tegas disebutkan dalam Pasal 8 UU SPA 2012. Undang-undang ini secara tegas mengatur bahwa prosedur diversi dalam perkara anak harus dilakukan dengan menggunakan pendekatan keadilan restoratif mulai dari tahap penyidikan hingga tahap persidangan.

Selain itu, Pasal 8 (2) UU SPA 2012 memungkinkan pelibatan pekerja kesejahteraan sosial dan atau masyarakat dalam proses diversi jika diperlukan. 16 Pasal ini serupa dengan Pasal 5 (2) Peraturan Pemerintah Republik Indonesia Nomor 65 Tahun 2015 tentang Pedoman Pelaksanaan dan Tindakan Diversi Terhadap Anak Di Bawah 12 Tahun. Artinya saat ini keikutsertaan pekerja kesejahteraan sosial dan atau masyarakat dalam proses diversi tidak bersifat wajib. Selain itu, karena restorative justice merupakan kunci dalam pelaksanaan diversi, maka Pasal 8 (3) UU SPA 2012 memberikan nilai-nilai dasar restorative peradilan anak. Ini adalah; kepentingan korban, kesejahteraan dan tanggung jawab pelaku remaja, tidak adanya stigmatisasi terhadap pelaku, tidak adanya balas dendam, kerukunan masyarakat, kepatutan, kerendahan hati dan keselamatan umum.

Selanjutnya, Pasal 9 (1) UU SPA 2012 mengatur bahwa dalam proses diversi polisi, jaksa dan hakim harus mempertimbangkan kategori kejahatan, usia anak, laporan petugas masa percobaan dan dukungan dari keluarga. Pasal 9 (2) Undang-undang tersebut dengan jelas menyatakan bahwa hanya korban dan atau keluarga korban yang harus menyetujui hasil diversi dan anak serta keluarga anak harus menyetujui akibat tersebut. Jelas bahwa konsepsi perjumpaan, sebagaimana dikemukakan oleh Johnstone dan Van Ness, dalam UU SPA 2012 tidak diakui dalam mencapai putusan diversi. Kemungkinan pelibatan pihak lain yang berada di luar anak dan korban tindak pidana beserta keluarganya dan penegak hukum formal dalam proses diversi, hanya bila dianggap perlu, bukan wajib.

Namun, persetujuan tersebut dapat diabaikan oleh polisi jika kejahatannya tidak serius atau pelanggaran ringan, kejahatan tanpa korban, dan jumlah kerugian korban tidak lebih dari upah minimum regional. Polisi dapat melibatkan anak dan korban tindak pidana dan keluarganya, petugas masa percobaan dan tokoh masyarakat. Pasal 93 (d) SPA 2012 mengatur tentang peran serta masyarakat dalam menyelesaikan perkara anak dalam proses diversi dan restorative justice. Berkenaan dengan konsepsi reparatif, sebagai salah satu konsep yang ditawarkan oleh Johnstone dan Van Ness, Pasal 10 SPA 2012 mengatur bahwa hasil dari diversi dapat berupa pemulihan finansial korban, rehabilitasi medis dan psikososial, mengembalikan pelaku ke tempat asalnya. orang tua atau wali, yang melibatkan pelaku dalam program pendidikan atau pelatihan di lembaga pendidikan atau Lembaga Khusus Perawatan Anak (LPKS) atau pengabdian masyarakat paling lama tiga bulan. Selain itu, sistem pemidanaan SPA 2012 adalah double track system karena memiliki pemidanaan dan perlakuan atau tindakan. Salah satu perlakuan dalam Pasal 82 (1) adalah mengembalikan kerugian pidana sebagai tanda restorative justice dalam sanksi perlakuan terhadap UU SPA 2012.

Pengesahan UU SPA 2012 yang menganut asas restorative justice tentu menjadi angin segar, memberikan harapan baru bagi evolusi hukum anak Indonesia. Masuk akal untuk mengatakan bahwa penerapan restorative justice ke dalam sistem peradilan pidana Indonesia sudah lama terjadi, mengingat KUHAP negara ini menekankan kepatuhan yang ketat terhadap hukum dan pengenaan hukuman pidana. 
Lebih lanjut, di pengadilan anak Indonesia, hak-hak anak terus dilanggar, seperti ditemukannya tuntutan hukuman mati dalam kasus-kasus yang melibatkan anak di bawah umur, hak untuk diwakili oleh orang tuanya, dan perampasan hak-hak anak. Anak-anak yang tidak berada dalam tahanan negara atau pemerintah tidak boleh bebas karena mereka dipenjarakan bersama-sama dengan anak negara dan anak kriminal. Pekerjaan sosial/bakti sosial dan pembebasan bersyarat merupakan contoh tindakan yang dapat dilakukan oleh anak terpidana, seperti pemberian hukuman bersyarat.

Dengan kata lain, dengan keadilan restoratif, proporsionalitas hukuman bagi anak di bawah umur cukup penting. Ketentuan dalam The Beijing Rules dan undang-undang PBB tentang perlindungan anak menunjukkan bagaimana model ini bekerja, dan mereka harus diperlakukan secara serius jika anak-anak ingin mendapatkan haknya sebagai tersangka dan sebagai anak-anak untuk dilindungi selama proses hukum. Ketika seorang anak dikeluarkan dari sekolah, misalnya, jaksa dapat menggunakan wewenangnya untuk mendeportasi seorang anak dalam keadaan tertentu. Artinya, untuk mencegah praktik hukum yang merugikan yang melukai anak, harus ada standar seragam yang mengatur kondisi dan pelaksanaan perlakuan nonformal.

Berdasarkan ciri-ciri keadilan restoratif di atas, ada syarat yang harus dipenuhi untuk mencapai keadilan restoratif, yaitu:

1) Harus ada pengakuan atau pernyataan bersalah dari pelaku;

2) Harus ada kesepakatan dari korban untuk melakukan penyelesaian di luar sistem peradilan anak yang berlaku;

3) Persetujuan dari kepolisian atau kejaksaan sebagai lembaga yang memiliki kewenangan diskresi.

Dalam pelaksanaannya, keadilan restoratif didasarkan pada beberapa prinsip:

1) Menjalin partisipasi bersama antara pelaku, korban dan kelompok masyarakat dalam menyelesaikan suatu peristiwa atau tindak pidana. Menempatkan pelaku, korban dan masyarakat sebagai pemangku kepentingan yang bekerja sama dan segera berusaha mencari solusi yang dipandang adil bagi semua pihak (win-win solution).

2) Mendorong pelaku/anak untuk bertanggung jawab atas korban peristiwa atau tindak pidana yang menimbulkan luka atau kerugian bagi korban. Selanjutnya, ia menetapkan tanggung jawab untuk tidak mengulangi tindak pidana yang telah dilakukannya.

3) Menempatkan peristiwa atau suatu tindak pidana terutama sebagai bentuk pelanggaran hukum antar individu, tetapi sebagai delik yang dilakukan oleh seseorang (group of person) dari orang tersebut (group of people). Oleh karena itu, pelaku harus diarahkan pada pertanggungjawaban terhadap korban, bukan mengutamakan tanggung jawab hukum (formal legal).

4) Mendorong penyelesaian suatu peristiwa atau tindak pidana secara lebih informal dan personal, bukan penyelesaian melalui prosedur formal di pengadilan (rigid and inpersonal).

Dengan kata lain, keadilan restoratif adalah suatu cara pandang terhadap sistem peradilan pidana yang berusaha mengatasi beberapa masalah dengannya. Untuk menjamin kondisi yang sama sebelum kejahatan terjadi dan untuk menghindari tindak pidana berikutnya, strategi ini digunakan sebagai kerangka strategis untuk penyelesaian kasus pidana yang melibatkan masyarakat, korban, dan pelaku. Untuk menangani kegiatan kriminal, keadilan 
restoratif berusaha untuk mencapai keseimbangan antara kepentingan korban, pelaku, dan masyarakat pada umumnya. Tidak ada norma ideal dalam mendefinisikan makna resmi keadilan restoratif karena gagasan tersebut masih berkembang dan mengarah pada interpretasi yang berbeda di berbagai negara.

\section{KESIMPULAN}

Kasus anak yang berkonflik dengan hukum yang dibawa ke proses hukum adalah kasus yang berat, dan kepentingan terbaik anak harus selalu diperhatikan. Proses hukuman harus dianggap sebagai upaya terakhir, dan hak-hak anak tidak boleh didiskusikan selama proses berlangsung. Dalam konteks restorative justice, melalui penyelesaian sengketa, konsep pilihan penyelesaian diserahkan kepada individu pelaku dan individu korban. Undang-Undang SPA di Indonesia yang disahkan pada tahun 2012, menetapkan kerangka bagi pelaksanaan peradilan anak restoratif yang dimulai dengan penggunaannya dalam proses diversi dan dapat meluas ke tahap pasca-hukuman. Dalam menentukan sanksi yang tepat, pelaku dapat memberikan ganti rugi kepada korban, yang harus dirundingkan dan disepakati oleh kedua belah pihak. Ketika semua pihak yang terlibat diperlakukan secara adil dan setara, secara aktif berpartisipasi dalam proses peradilan, dan menerima manfaat yang memadai dari interaksi mereka dengan sistem peradilan anak, gagasan tersebut menyatakan bahwa keadilan dilayani dengan baik dan bahwa sistem tersebut paling efektif.

\section{REFERENSI}

Ariani, N. V. (2014). Implementasi Undang-Undang Nomor 11 Tahun 2012 tentang sistem peradilan pidana anak dalam upaya melindungi kepentingan anak. Jurnal Media Hukum, 21(1), 16.

Arief, B. N. (1998). Beberapa Aspek Kebijakan Penegakan dan Pengembangan Hukum Pidana. Citra Aditya Bakti.

Ariman, M. R., \& Albariansyah, H. (2014). Perlindungan Hukum terhadap Anak sebagai Korban Tindak Pidana Perdagangan Anak(Doctoral dissertation, Sriwijaya University).

Fadri, I. (2010). Kebijakan Kriminal Penanggulangan Tindak Pidana Ekonomi di Indonesia. Jurnal Hukum, (3), 430-455.

Fathurokhman, F. (2013). The necessity of restorative justice on juvenile delinquency in Indonesia, lessons learned from the Raju and AAL cases. Procedia Environmental Sciences, 17, 967-975.

Hambali, A. R. (2019). Penerapan diversi terhadap anak yang berhadapan dengan hukum dalam sistem peradilan pidana. Jurnal Ilmiah Kebijakan Hukum, 13(1), 15-30.

Hasibuan, S. A. (2019). Kebijakan Kriminal (Criminal Policy) Terhadap Anak yang Melakukan Kekerasan dalam Rumah Tangga. Jurnal Hukum Responsif, 7(2), 17-29.

Kusumaatmadja, M. (1976). Hukum, Masyarakat dan Pembinaan Hukum Nasional. LPHK, FH Unpad, Bina Cipta, Bandung.

Purwati, A., \& Alam, A. S. (2015). Diversi Sebagai Wujud Kebijakan Pemidanaan dalam Sistem Peradilan Pidana Anak di Indonesia. De Jure: Jurnal Hukum dan Syar'iah, 7(2), 181-190. 
Salam, S. (2017). Hukum Dan Perubahan Sosial (Kajian Sosiologi Hukum). TAHKIM, 11(1).

Setiadi, H. E. (2017). Sistem Peradilan Pidana Terpadu dan Sistem Penegakan Hukum di Indonesia. Prenada Media.

Soekanto, S. (2007). Penelitian Hukum Normatif: Suatu Tinjauan Singkat. Jakarta: Raja Grafindo Persada.

Suntoro, A. (2020). Penyadapan dan Eksistensi Dewan Pengawas Komisi Pemberantasan Tindak Pidana Korupsi. Jurnal Legislasi Indonesia, 17(1), 25-37.

Undang-Undang Nomor 11 Tahun 2012 tentang Sistem Peradilan Pidana Anak.

Undang-Undang Nomor 35 Tahun 2014 tentang Perlindungan Anak.

Undang-Undang Nomor 39 tahun 1999 tentang Hak Asasi Manusia.

Waqiah, S. Q. (2021). Perlindungan Perempuan dan Anak Menurut Perspektif Hukum Kontemporer. An-Nawazil: Jurnal Hukum dan Syariah Kontemporer, 2(02), 55-70. 